\title{
Nuclear Structure Data File A Manual for Preparation of Data Sets
}

\author{
W. B. Ewbank \\ M. R. Scinmorak \\ F E. Bertrand \\ M. Feliciano \\ D. J. Horen
}

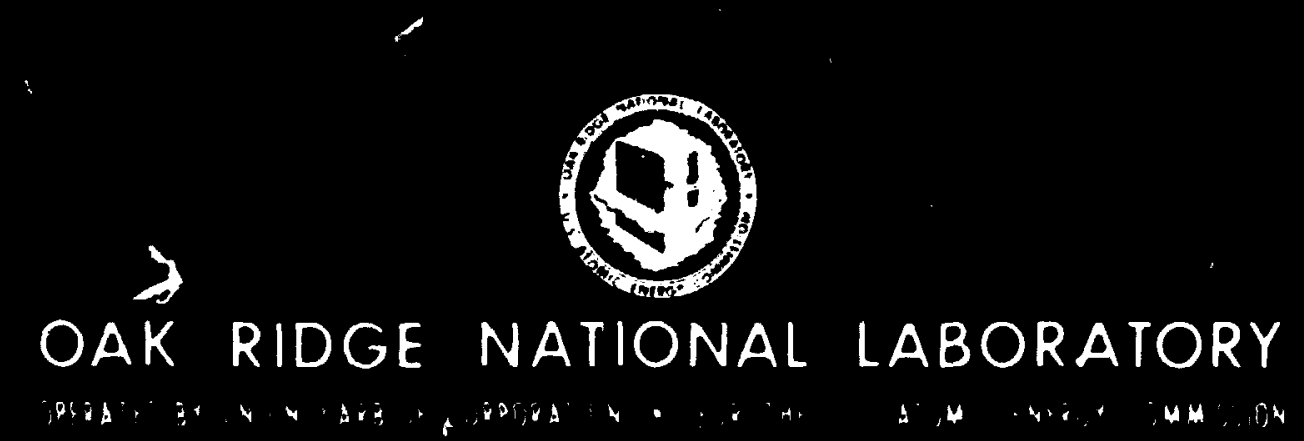




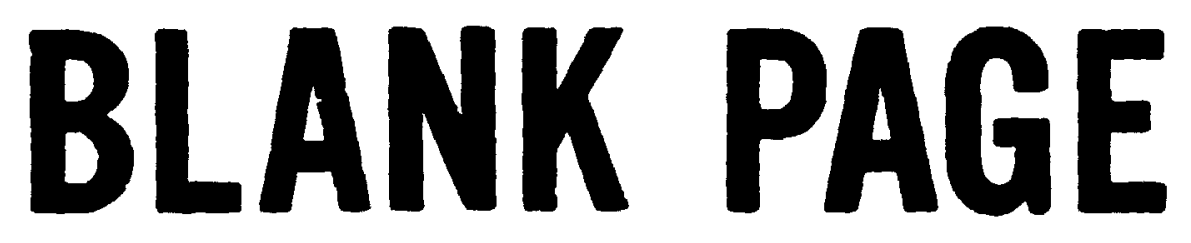


Primed in the Unitud States of America. Avaluble from National Technical Informetion Service U.S. Deportmeme of Commerce 5205 Port Royal Road. Sar ngliedd. Vinginia 22161 Price: Prinud Copy S4.00: Mroofiche $\$ 2.25$

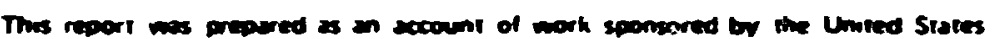

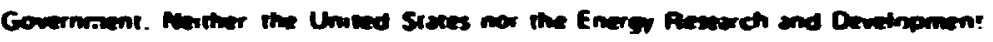

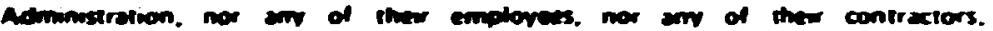

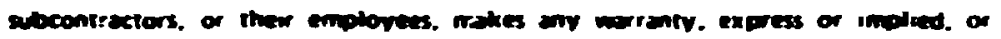

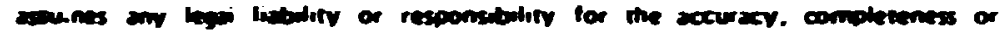
undutwes of on informption. apperates. product or procass desdosed. or represents

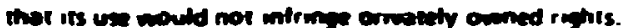


Contract No. W-7405-eas-26

Nuclear Data Project

NUCleaR StRUCTURE DATA FILE.

A Maralal for Preparation of Data Sets

W. B. Eubenk M.R. Schmorak F.E. Bertrand

M. Feliciano D. J. Horen

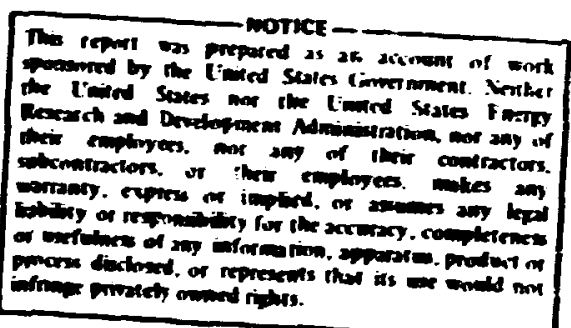

June 1975

OAK RIDGE NATIONAL LBORATORY

Oak Ridge, Tennessee $3 ; 830$

operated by

UNION CARBIDE CORPORATION

for the

ENERGY RESEARCH ND DEVELOPIENT ADMINISTRATION 
CONTENTS

I. INTRODUCTION ................ 1

II. GENERAL STRUCTURE OF THE DATA FILE ..... 2

A. Introduction

B. Summary of Data Set Structure

III. STANDARD ONE-CARD RECORD FORMATS . . . . 3

A. Introduction

B. The Standard One-Card Record Formats

C. Summary

IV. PREPARING FORMAT RECORDS ......... 13

A. Introduction

B. Organization of the Format Record

C. Allowed Data Types

v. RECOROS CONTANING MORE THAN ONE CARD . . 16

A. Card Enumeration

B. Formats for Continuation Cards

VI. DETAILED FIELD DESCRIPTIONS . . . . . . . 18
A. NUCID
B. DSID
C. DSREF
D. RTYPE

VII. UNCERTANTTES . . . . . . . . . . 21

A. Standard Numeric Uncertainties

B. Non-numeric Uncertainties

VIII. EXPECTED AND ALLOWED UNITS . . . . . . . . 22

IX. FREE-FORM FIELDS. . . . . . . . . . 22

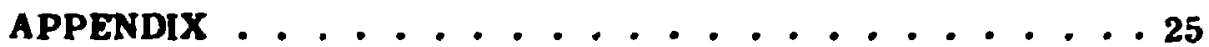




\title{
NUCLEAR STRUCTURE DATA FILE
}

A Manual for Preparation of Data Sets

\author{
W. B. Ewbank M.R. Schmorak F.E. Bežrand \\ M. Feliciano, Jr.* D. J. Horen
}

\section{DNTRODUCTION}

The Nuclear Data Project at ORNL is building a computer-based file of mclear structure data, which is intended for use by both basic and applied users. For every uucleus, the Nuclear Structure Data File ASDF) contaim evaluated puclear structure information taken from the Nuclear Date Bheets as well as from other publiahed data evaluations. In addition, the file will incorporate such important new data as may have become available since the most recent prodished evalusicion. It is hoped that welear 3tructure research worters will participate in buiiding the Data File by preparing their new data in such a form that it can eavily be included. It is desired that the Data File represent the best curreatly availsole nuclear structure data.

This mamual describes a standard input format for melear structure data. The format is sufficiently structured that bulk data can be eatered efficiently. At the same time, the structure is open-ended and can accommodate mout mesanred or deduced quantities that yield muclear st ructure information.

The Data File will be used by both basic and applied scientists and engineers. The Nuclear Data Project is using the Data File to prepere Nuclear Data Sheets. collections of specific muclear properties and of particular types of experimeatal information. Computer programs have been developed at the Data Project to porform consistency checking and routine calculations. Programs are also used for preparing level scheme drawings and for reformating the muclear structure data for special tabular presentation. Data extracted from the Nuclear Structure Data File will also be used by the Data Project to respond to specific requeats from the nuclear community for current muclear st ructure information.

*Present address: The Aerospace Ccrporation, Ins Angelea, California 90009. 


\section{Gengahl STRuctuRE OF THE DATA FLE}

\section{A. Introdection}

The Neclear Structure Dan File ASDP) is ands up from a collection of "dnte sets", each of wich describes the revilts a a sinde experinemt or the combined eveluated recults of a nuber of eqperiments of sice same type. The

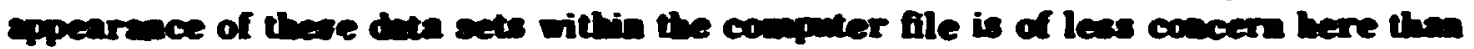
is the ppearace of the dat sets either before thy emer the computer or after

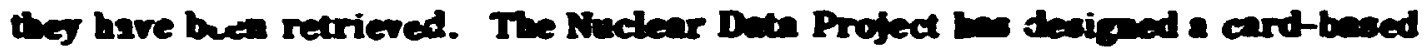

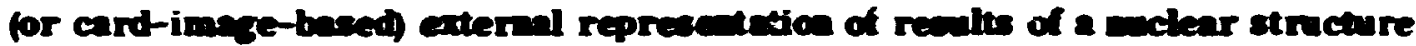
experimen, which nas be used for proparies inpat to the comster file and for exchnge of information retrieved from the conpler file. In the reaninder of this momal, we shall refier to the grup of caris or eard imeges a a dan set, evea though it is understood to be obly 2 external version of the inenal bas set

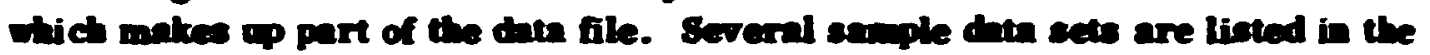
Appendix.

\section{B. Sumang of Deta Set Structure}

A data set is composed of recouds; each record is unde up of ane or more card imeges.

A date set mat begin with a IDENTIFCATIOA record (with label information) and wast end with a BND record (a blat cards. Between these two records, there will be as mang atitional records as are needed to deacribe filly the experiment or the evaluated data set.

Immediately following the IDZWTIFICATION record is a group of records which contain information sbout the entire data set. The NORMALZATION (N), Q-VALUE R), PORMAT (F), and PAREAT (P) record are of this tspe.

The body of a data set is composed of mameric data records which describe the measared or deduced propertice of levels, y-rass, a-particles, elc. These records are aseociated with the level wifich decass (bor GAMMA records) or the level which is populated (for B+, B-, EC, or ALPAA records). Thus, esch LEVEL recond is followed by a group of records describing charged-particle decay into the level and r-ray deces ont of be level.

If a GAMMA record (or ALPHA or B+ or B-) properly belong in a duta set, but it canot be ascociated with any particular level, then the record jaxy be placed in the date set before an LEVEL records. 
COMMENT records (C) may appear in the data set wherever they seem most approgriate. General remarks will usually follow the IDENTIFICATION record, while comments boul a specific number should follow the recond which contains that number.

\section{STANDARD ONE-CARD RECORD FORMATS}

\section{A. Impoduction}

In most cases, ail information for a recond can be placed on a single 80column cari. A "stondan'" format has been defined for each one-card record, such that the most commonly used gramities can be placed on a single card. The standard formans are deacribed in this section for mach record. If a meeded quantity is not included in the stantand formal or if a value will not fit within the field defined for the value by the stadard forma, then A FORMAT record will be required (see Section IV). If a record canot be comined on a single card, then additional cards can be prepared as described in Section $V$.

\section{B. The Standard One-Cand Record Formats}

Record formats are givea below in the same order in which they would pormally be vacountered in a data set. Conditions under which each record may appear or be required are given in pareatheses. The format descriptions give the fields (in incluaive card-colnm mubers), the field namea (the formal "name" of the quatity that goes into the field), and a brief field description. Cand colunms not explicitly inctuded is the flelds are expected to be blank. Additional information about each field can be found in the reference section noted. 
1. THE IDXNTIFICATION RECORD

(Required for all data sets)

\begin{tabular}{|c|c|c|c|}
\hline Field & Name & Descriptios & Reference \\
\hline Col. 1-5 & NuCD & Nuclens identification & $\mathbf{V 1 . A}$ \\
\hline 8 & & Muat be blast & \\
\hline $10-39$ & DED & Datn set ideatification & V1.B \\
\hline $40-74$ & DSREF & Date set refereaces & V1.C \\
\hline $75-80$ & DATE & $\begin{array}{l}\text { The dace vear/month } \\
\text { duta ced wos pleced }\end{array}$ & \\
\hline
\end{tabular}

\section{THE POAMAT BECORD}

(Required oaly if the stagdard format is oot weed. See Section IV)

\begin{tabular}{|c|c|c|c|}
\hline Pleld & Name & Deseriptos & Reference \\
\hline Col. 1-5 & NuCiD & Nuclons idedificmion & VI.A \\
\hline $\mathbf{7}$ & $\boldsymbol{F}$ & Letter "po" is required & \\
\hline 8 & RTYPE & Bccord type being formatted & VI.D \\
\hline $10-80$ & FORMATS & 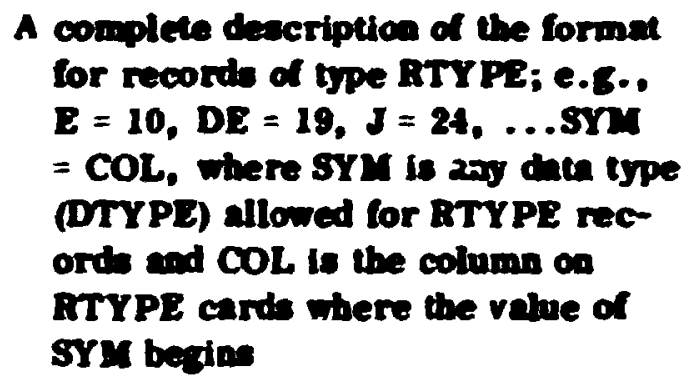 & \\
\hline
\end{tabular}

\section{THE COMIENT RECORU}

(Optional with any data set)

\begin{tabular}{|c|c|c|c|}
\hline Field & Name & Description & Reference \\
\hline Col. 1-5 & NUCID & Nuclew identification & VI.A \\
\hline $\boldsymbol{T}$ & $\mathbf{C}$ & Letter "C" is reguired & \\
\hline 8 & RTYPE & Record type being commented upon & VI.D \\
\hline
\end{tabular}



10-19 SYM (FLAG) SYM = type of data being commented JV.C upon, or a special word (e.g.,
BAXD) describing some common feature of a group of records
FLAG - character in col. 77 of all level or gamma records to which the comment applies
If FLAG is omitted, then the comment is understood to apply to all records of type RTYPE
20-80 CTEXT TEXT of the commen
Comment records may also be used to give numeric data which is not incheded elsewhere in the dua set, e.g., X-rays, andihilation radiation

\section{THE MORMAUZATION RECORD}

(Recuired if as absolute normalization is possible; used mainly with decay data sets)

$\begin{array}{cl}\frac{\text { Field }}{\text { Col. 1-5 }} & \text { Name } \\ 8 & \text { NUCID } \\ 10-19 & \text { NR } \\ & \\ & \\ 20-21 & \text { DNR } \\ 22-29 & \text { NT }\end{array}$

Deecription

Reference

Nuclens identification

VI.A

Letter " $\mathrm{N}$ " is required

Multiplier for coaverting relative photon incensity to photones per 100 decays of the parent through the decay branch. Recuired if aboolute photon intensity can be calculated

Standard uncertainty in NR

VII

Mnltiplier for coaverting relative transition intensity (including conversion electrons) to irnations per 100 decays of the parent through this decay branci:

30-31 DNT

Standard uncertainty in NT

VII

32-39 BR

Branching ratio multiplier for converting inteasity per 100 deceys through this decay branch to intensity per 100 decays of the parent macleus. Required if loown 
5. THE PARENT RECORD

(Optional, bat desirable for decay data sets)

\begin{tabular}{|c|c|c|c|}
\hline Field & Nane & Description & Refereace \\
\hline Col. 1-5 & NuCiD & $\begin{array}{l}\text { Nuclens identification for pareat } \\
\text { melaus }\end{array}$ & VI.A \\
\hline 8 & $\mathbf{P}$ & Letter "P" is required & \\
\hline $10-19$ & $\mathbf{E}$ & Enery of the decaying level in teV & \\
\hline $20-21$ & $\mathbf{D E}$ & Standard uncertains in E & VII \\
\hline $22-39$ & $\boldsymbol{J}$ & Spin or parity or both & \\
\hline $40-49$ & $\mathbf{T}$ & Half-life; uits mast be given & VIII \\
\hline $50-55$ & $\mathbf{D r}$ & Stendard uncertainty in $T$ & VII \\
\hline $65-74$ & $\mathbf{Q P}$ & 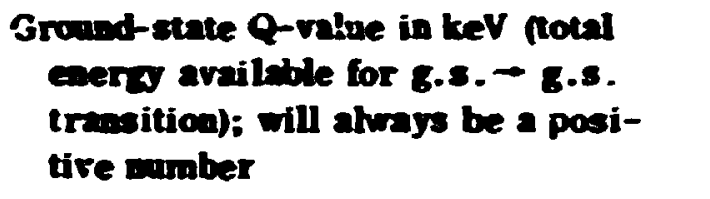 & \\
\hline $75-76$ & DQP & Standard uncertainty in QP & vi \\
\hline \multicolumn{4}{|c|}{$\begin{array}{l}\text { 6. THE Q-VALUE RECOAD } \\
\text { Optional in most data setsi }\end{array}$} \\
\hline Field & Name & Description & Reference \\
\hline Col. 1-5 & NUCTD & Nuclens identification & VI.A \\
\hline 8 & $\mathbf{Q}$ & Leter "Q" is required & \\
\hline $10-19$ & $\mathbf{Q}^{-}$ & $\begin{array}{l}\text { Total energy (teV) avai able for } \frac{\beta^{-}-}{>0} \\
\text { decy of the grount siate. } Q^{-} \\
\text {if } \beta^{-} \text {-decay is eacrgetically possible }\end{array}$ & \\
\hline $20-21$ & $\mathbf{D Q}^{-}$ & Standard uncertainty in $Q^{-}$ & VII \\
\hline 22-29 & SR & Nertron separation eaery in keV & \\
\hline $30-31$ & Des & Standard uncertainty in SN & VII \\
\hline $32-39$ & SP & Proton separation enerng in keV & \\
\hline $40-41$ & DSP & Stadard uncertainty in SP & VII \\
\hline 42-49 & $\mathbf{Q A}$ & $\begin{array}{l}\text { Total enera (kev) avallable for as } \\
\text { decay of the ground state }\end{array}$ & \\
\hline $50-55$ & DQA & standard uncertainty in QA & VII \\
\hline $56-80$ & $\mathbf{R E F}$ & Reference citation(s) f(.r the Q-values & \\
\hline
\end{tabular}




\section{THE LEVEL RECORD}

Mptican, albough a data set usually has at least one)

\begin{tabular}{|c|c|c|c|}
\hline Field & Name & Description & Reference \\
\hline Col. 1-5 & StCTD & sucleus ideatification & VI.A \\
\hline 8 & $\mathbf{L}$ & Letter " $L "$ is required & \\
\hline $10-19$ & $\mathbf{E}$ & Level esersy in keV & \\
\hline $20-21$ & $\mathbf{D E}$ & Standard uncertaisty in $\mathbf{E}$ & VII \\
\hline 22-39 & $\mathbf{J}$ & Spin or parity or both & \\
\hline $10-49$ & $\mathbf{T}$ & $\begin{array}{l}\text { Half-life of the level; units must be } \\
\text { givea }\end{array}$ & VIII.A \\
\hline $50-55$ & $\mathbf{D T}$ & Standard uscertainty in $T$ & VII \\
\hline $56-64$ & $\mathbf{L}$ & $\begin{array}{l}\text { Anglar momentum transfer in the } \\
\text { reaction determining the data set. } \\
\text { Whether it is } \ell_{n}, l_{0} \delta \text {, etc. is } \\
\text { determined from the DSID field } \\
\text { of the IDENTIFICATIOA recond }\end{array}$ & \\
\hline $65-74$ & $\mathbf{s}$ & $\begin{array}{l}\text { Spectroscopic factor for this level as } \\
\text { determined from the reaction in the } \\
\text { IDENTIFICATION record }\end{array}$ & \\
\hline $75-76$ & $\mathbf{D S}$ & Standard uncertainty in S & vII \\
\hline 77 & $\mathbf{c}$ & $\begin{array}{l}\text { Comment FLAG (see Section III. B.3) } \\
\text { used to refer to a particular com- } \\
\text { meat record }\end{array}$ & \\
\hline $78-79$ & MS & $\begin{array}{l}\text { Metantable state is denoted by } M \text { or } \\
\text { M1 for the frst isomer; M2, for } \\
\text { the second, etc. }\end{array}$ & \\
\hline \multirow[t]{2}{*}{80} & $\mathbf{Q}$ & $\begin{array}{l}\text { The charncter " ?" denotes an uncer- } \\
\text { tain or questionable level }\end{array}$ & \\
\hline & & $\begin{array}{l}\text { Letter "g" denotes neutron or proton } \\
\text { separation energy }\end{array}$ & \\
\hline
\end{tabular}




\section{THE GAMMA RECJRD}

Pptional. Must follow the LEVEL record for the level from which the y-ray decays. Records for $y$-rays which are unassigned in a level scheme should precede the first level of the data set.)

\begin{tabular}{|c|c|c|c|}
\hline Field & Name & Description & Reference \\
\hline Col. 1-5 & NUCID & Nucleus identification & VI.A \\
\hline 8 & $\mathbf{G}$ & Letter " $G$ " is required & \\
\hline $10-19$ & $\mathbf{E}$ & Energy of the $\mathrm{Y}$-ray photon in keV & \\
\hline $20-21$ & $\mathbf{D E}$ & Standard uncertainty in $\mathbf{E}$ & VII \\
\hline $22-29$ & $\mathbf{R I}$ & Relative photon intensity & \\
\hline 30-31 & DRI & Standard uncertainty in RI & VII \\
\hline $32-41$ & $\mathbf{M}$ & Multipolarity of transition & \\
\hline $42-49$ & $\mathbf{M R}$ & $\begin{array}{l}\text { Mixing ratio 6. (Sign must be shown } \\
\text { explicitly if known. If no sign is } \\
\text { given, then the number given is an } \\
\text { absolute value.) }\end{array}$ & \\
\hline $50-55$ & DMR & Standard uncertainty in $\mathbf{M R}$ & VII \\
\hline $56-62$ & $\mathrm{CC}$ & Total conversion coefficient & \\
\hline $63-64$ & DCC & Standard uncertainty in CC & VII \\
\hline $65-74$ & rI & Relative total transition intensity & \\
\hline $75-76$ & IITI & Standard uncertainty in TI & VII \\
\hline 77 & $\mathbf{C}$ & $\begin{array}{l}\text { Comment FLAG isee Section III.B.3) } \\
\text { used to refer to a particular com- } \\
\text { ment record }\end{array}$ & \\
\hline 78 & ORG & $\begin{array}{l}\text { Letter "C" denotes coincidence with a } \\
\text { preceding radiation }\end{array}$ & \\
\hline 79 & END & $\begin{array}{l}\text { Letter "C" denotes coincidence with a } \\
\text { following radiation }\end{array}$ & \\
\hline \multirow[t]{2}{*}{80} & $\mathbf{Q}$ & $\begin{array}{l}\text { The character "?" denotes an uncertain } \\
\text { or questionable line or an uncertain } \\
\text { placement of the transition }\end{array}$ & \\
\hline & & $\begin{array}{l}\text { J,etter "S" denotes an expected, but as } \\
\text { yet unobserved, transition }\end{array}$ & \\
\hline
\end{tabular}




\section{THF $\beta^{-}-$RECORD}

(Optional. Must follow the IEVEL record for the level which is fed by the $\beta^{-}$.)

$\begin{array}{cl}\text { Field } & \text { Name } \\ \text { Col. 1-5 } & \text { NUCID } \\ 8 & \text { B } \\ 10-19 & \text { E } \\ 20-21 & \text { DE } \\ 22-29 & \text { IB } \\ 30-31 & \text { DIB } \\ 42-49 & \text { LOGFT } \\ 50-55 & \text { DFT } \\ 77 & \text { COIN } \\ 78-79 & \text { UN } \\ 80 & Q\end{array}$

Description

Nucleus identification

Letter " $B$ " is required

Endpoint energy of the $\beta^{-}$in $\mathrm{keV}$ only if measured

Standard uncertainty in $\mathbf{E}$

Intensity of the $\beta$-decay branch in percent of the total $\beta^{-}$-decay

Standard uncertainty in IB

Log $f$ for the $\beta^{-}$-transition

Standard uncertainty in LOGFT

Letter " $C$ " denotes coincidence with a following radiation

Uniqueness classification for the $\beta^{-}-$ decay, e.g., 1U, 2U; a blank signifies an allowed transition

The character "?" denotes an uncertain or questionable $\beta^{-}$-decay

Letter "S" denotes an expecter nr predicted transition
VII

VII

VII

Reference

VI. A

10. THE EC (or EC $+\beta^{+}$) RECORD

(Optional. Must follow the LEVEL record for the level being populated in the decay.)

$\begin{array}{cl}\stackrel{\text { Field }}{\text { Col. 1-5 }} & \text { Name } \\ \text { F } & \text { E } \\ 10-19 & \text { E } \\ & \\ 20-21 & \text { DE } \\ 22-29 & \text { IB }\end{array}$

Description

Reference

Nucleus identification

VI. A

Letter "E" is required

Energy for electron capture to the level only if measured

Standard uncertainty in $\mathbf{E}$

VII

Intensity of $\beta^{+}$-decay branch in percent of the total $\left(\epsilon-\beta^{+}\right)$-decay

30-31 DIB

Standard uncertainty in IB 


\begin{tabular}{|c|c|c|}
\hline $32-39$ & $\mathbf{I E}$ & $\begin{array}{l}\text { Intensity of elc. tron capture branch } \\
\text { in percent of total }\left(k+\beta^{+}\right) \text {-decay }\end{array}$ \\
\hline $40-41$ & DIE & Standard uncertainty in IE \\
\hline $42-49$ & LOGPT & Log $f$ for $\left(\xi+\beta^{+}\right)$-transition \\
\hline $50-55$ & DFT & Standard uncertainty in LOGFT \\
\hline $65-74$ & $\mathbf{T I}$ & Toul $\left(\kappa+\beta^{+}\right)-$decy intensity is percent \\
\hline $75-76$ & DTI & Standard uncertainty in $\mathbf{T}$ \\
\hline 77 & COIN & $\begin{array}{l}\text { Letter " } C \text { " denotes coincidence between } \\
\beta^{+} \text {and a following radiation }\end{array}$ \\
\hline $78-79$ & UN & $\begin{array}{l}\text { Uniqueness classification for } \epsilon, \beta^{+}- \\
\text {decay, e.8., 1U, 2U; blenk sigai- } \\
\text { fies an allowed transition }\end{array}$ \\
\hline 80 & $\mathbf{Q}$ & $\begin{array}{l}\text { The character " ?" denotes an uncertain } \\
\text { or questionable } \epsilon-, \beta^{+} \text {-branch }\end{array}$ \\
\hline & & $\begin{array}{l}\text { Letter "S" denotes an expected or pre- } \\
\text { dicted transition }\end{array}$ \\
\hline
\end{tabular}

\section{THE ALPHA RECORD}

(Optional. Must follow the LEVEL record for the level being populated in the decay.)

\begin{tabular}{|c|c|c|c|}
\hline Field & Name & Description & Reference \\
\hline Col. 1-5 & NUCID & Nucleus identification & VI. A \\
\hline 8 & A & Letter "A" is required & \\
\hline $10-19$ & $\mathbf{E}$ & Alpha enersy in keV & \\
\hline $20-21$ & $\mathbf{D E}$ & Standard uncertainty in $E$ & VII \\
\hline $22-29$ & IA & $\begin{array}{l}\text { Intensity of } \alpha \text {-decay branch in percent } \\
\text { of the total } \alpha \text {-decay }\end{array}$ & \\
\hline $30-31$ & DIA & Standard uncertainty in IA & VII \\
\hline $32-39$ & $\mathbf{H F}$ & Hindrance factor for $a$-decay & \\
\hline $40-41$ & DHF & Stendard uncertainty in HF & VII \\
\hline 77 & COIN & $\begin{array}{l}\text { Letter " } C \text { " denotes colncidence with } \\
\text { following radiation }\end{array}$ & \\
\hline \multirow[t]{2}{*}{80} & $\mathbf{Q}$ & $\begin{array}{l}\text { The character "?" dersotes uncertain } \\
\text { or questionable } ; \text {-branch }\end{array}$ & \\
\hline & & $\begin{array}{l}\text { Letter "S" denotes an expected or pre- } \\
\text { dicted } a \text {-branch }\end{array}$ & \\
\hline
\end{tabular}



STANDARO FORMATS

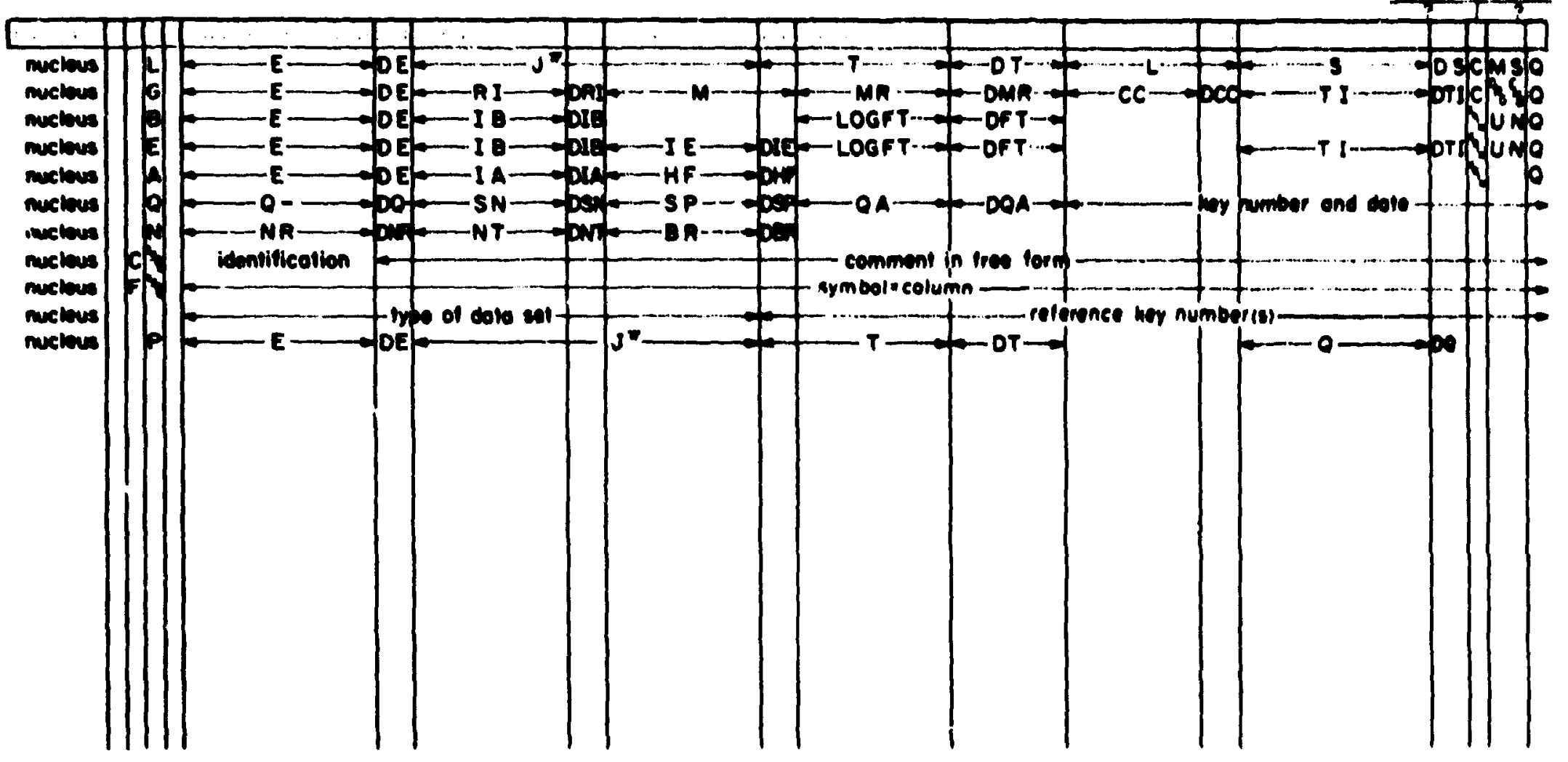




\section{PREPARING FORMAT RECORDS}

\section{A. Introduction}

If the standard cose-card formats described in Section III. B are used, then there is wo need to include a FORMAT record. A FORMAT record is required if the data items in a cose-card recond are too wide for the standard fields or if the data appear in an order different from the standard record or if data of a noastanhard type are to be inchuded on the ooe-card record. (Use of the FORMAT recond should be avoided whenerer possible.) Only the first card of a record may have its orzanization described by a PORMAT record. Contimation cards for the record will always contain their own format information (see Section V). A FORMAT record may not be used for the IDENTIFTCATION recond, a CUMMENT record, the NORMALZATION record, the Q-RECORD, the END record, or mother FORMAT record.

\section{B. Orranization of the FORMAT Record}

The PORMAT record will always sontain the letter "F" in col. 7 and a character RTYPE (see Section VI.D) in col. 8 to identify the type of record the format of which is being specified by the FORMAT record. The FORMAT record consists of a single card for each record type for which a format is described. Contiouation cands are not allowed. The text of the FORMAT record is contained in cols. 10-80. The text cnasists of a series of equalities separated by commas or blanks; e.g., $E=10, D E=20, J=23, L=40$. In general, the form DTYPE = COL in a PURMAT reiord implies that the dath of type DTYPE are always contaired in a field beginaing in column COL of the RTYPE record. By implication, the field width includes all space up to the next larger value of COL given for some other data type DTYPE.

If a FORMAT record is used, care must be taken to avoid conflicting format specifications. The same data type may not be identified with more than one location on the data record; i.e., $E=10, E=25$ is in error.

Since each field width is assumed to be the maximum available for the particular data type, it is important to specify the complete format of the record RTYPE. If the text of the PMAMAT record for level records is $E: 15, J=25$, $T=40$, then tea card columns are allowed for $E, 15$ for $J$, and 41 columns are allowed for $T$. If any level $r$ zcord contains other information, e.g., the ietter " $c$ " for "unresolved doublet" in col. 77, then a atrange value for the half-life $(T)$ will be inferred since the information is within the field defined for " $T$ " type information. 


\section{Allowed Data Types}

Each record type is permitted to contain oaly a limited (but extendable) set of data types. For example, a GAMMA record is not allowed to contain information of data type DTYPE = J (muclear spin). Neither may a level record contain LOGFT information. For each record type, the following table lists the data types permitted as of April 15, 1975.

1. The PARENT Record

2. The Q-VALUE Record

All allowed data types are included in the standard format description in Sections III. B.5 and III. B.6.

\section{The LEVEL Record}

Allowed data types, E, DE, J, T, DT, L, S, DS, C, MS, Q, are describunt with the standard formats in Section III.B.7. Additional allowed data types are:

\section{DTYPE}

MV

DMV

UEV, UKV, UMV

PE

UE

A

SIGNG

SIGNA

qEC, \%SF, qIT, \%B-, $q B+, q A, q P, q N$

G

MOME1, MOME2, ...

момм1, Момм2, ...

CONF

$\boldsymbol{F}$

BE1, BE2, ...
Description

Level energy in MeV

"Standard" uncertainty in MV (Secturn VII)

Un ertainty in level energy, expressed in eV, keV, and MeV, respectively

Percent uncertainty in level energy

Uncertainty in level energy, given in same units as the level energy itself

Percent isotopic abundance

Thermal-neutron capture cross section

Total thermal-neutron absorption cross section

Percent decay of the level by electron capture, spontaneous fission, isomeric transitions, or emission of a $\beta^{-}, \beta^{+}, \alpha$, proton, neutron

g-factor of the level

Electric moments: dipole, quadrupole, ...

Magnetic moments: dipole, çuadrupole, ...

Nuciear configuration of the level

A "free-form" Geld (gee Section IX)

Reduced electric transition probability (upward) given in units $e^{2} \times$ (barno) $L$, where $L=1,2, \ldots$ for the transition from the ground state to this level 


\section{The GaMMa Recond}

Allowed date types, E, DE, RI, DRI, M, MR, DMR, CC, DCC, T!, DTI, C, ORG, END, Q, are described with the standerd formats in Section III.B.8. Additional allowed data types are:

DIYPE

MV

DMV

UEV, UKS, UMV

PE

UE

BE1, BE2, ...

BM1, BM2, ...

CEK, CEL, CEL1, ...

KC, LC, L1C, ...

EKC, ELC, ELIC, ...

$\mathbf{K} / \mathbf{L}, \mathbf{M} / \mathbf{L}, \mathbf{L} \mathbf{L} / \mathbf{L}, \ldots$

$K / T, L / T, \ldots$

PRI, PTI

URI, UTI

$\mathbf{F}$

\section{Description}

Camma eners in MeV

"Standard" uncertainty in MV Fection VII)

Uncertaindy in y-eaersy, expressed in eV, keV, and MeV, respectively

Percest uncertainty in Y-enersy

Uncertainty in renersy, given in same units as the reners itself

Reduced electric transition probsbility (downward) given in units of $\mathrm{e}^{2} \times$ (barma) $\mathrm{L}$, where $\mathrm{L}=1,2, \ldots$

Reduced magnetic transition probability (downward) given in units of $\mu_{N}^{2} \times$ (bams) $L$, where $L=1,2, \ldots$

ce-imensity for $K, L, L_{1}, \ldots$ converaion

Theoretical K-, L-, L 1 -conversion coefficieat

Measured K-, L-, $L_{1}$-conversion coefficient

ce-intensity ratios

Ratio of K, L, ... ce-intendity to total $(y+c e)$ intensity

Percentage uncertainty in $\mathrm{RI}, \mathrm{TI}$

Uncertainty in RI, TI, given in same units as RI, $\mathrm{T}$

A "free-form" field (see Section IX)

5. The $\mathrm{B}^{-}$Record

Allowed data types, E, DE, IB, DIB, LOGFT, DFT, COIN, UN, Q, are described with the standard formats in Section III. B.9. Additional allowed data types are:

DTYPE

MV

DMV

UEV, UKV, UMV

UE

\section{Description}

Beta energy in MeV

"Stemdard" uncertainty in MV (Bection VII)

Uncertainty in $\beta$-energy, given in eV, keV, MeV, respectively

Uncertainty in $\beta$-energy, given in same units as enerny 
PE

EAV

$\mathbf{F}$
Percentere uncertainty in $\beta$-esery

Arernge energs of the $\beta$-spectrum

A "free-form" fiold pee Sectice D)

Allowed date types, E, DE, IB, DB, IE, DE, LOGFT, DFT, T, DT, CON, Ux, Q, sre described with the standard formats in Section II. B. 10. Additional allowed date types are:

DIYPE

MV

Dany

UEV, UKY, UAY

UE

PE

EAV

$\mathbf{K}, \mathbf{L}, \mathbf{M}, \mathbf{N}+$

$\mathbf{F}$

\section{Deacription}

Eeerd for electron cepure to a level, given in MeV

"studind" necertaing is MV fection VII)

Uscertainty in capanre enersy, given in eV, keV, MeV, reppectively

Uncertainty in capture enerd, given in same units as the eners itcelf

Perceatuge nocertaibs in capture corers

Average carers of the $\beta^{+}$-spectrum

Fraction of decay by electron capture from the K, L, $\mathbf{M}, \mathbf{N}+\mathbf{O}+\ldots$ shells

A "free-form" Ineld (cee Section IX)

7. The ALPHA Record

All allowed date types are incladed in the standard format description in Section III.B.11.

\section{RECORDS CONTANING MORE THAN ONE CARD}

\section{A. Card Emaneration}

If all the inbrimation for a diven recond tspe canot be contained on a single eard, then it is pecalble to use ediflicand cards to describe the record tully. The

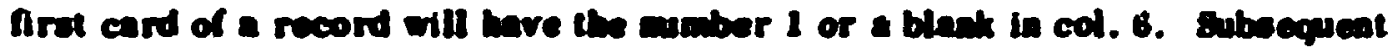

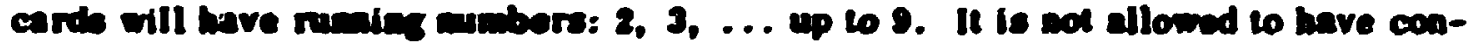

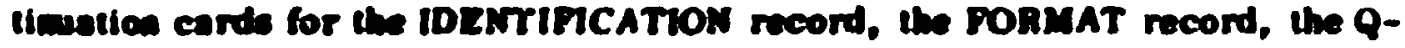

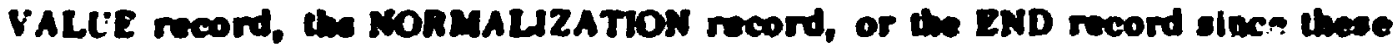

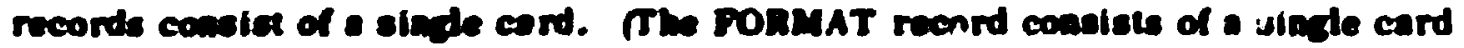
for each recond ispe lor which a spectal format is deseribad.) 


\section{B. Formats for Continantion Cands}

The secoad, thind, etc., cards of a record do not have a standard format. The data anst be presented in free-field format (Sectiva IX). For example:

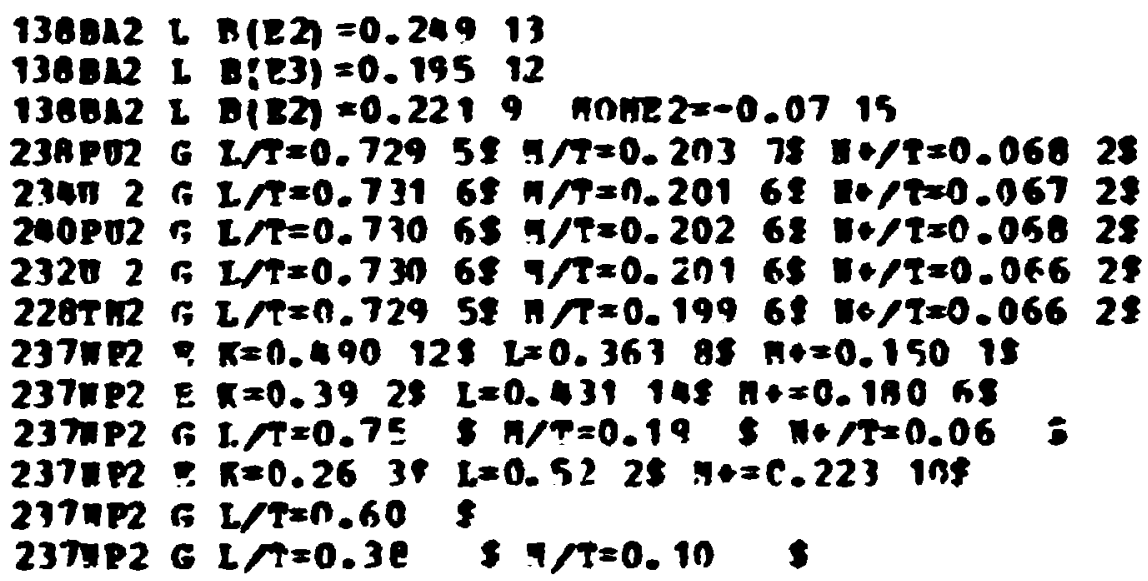

The data types given on continuation cards are limited to the set of names listed under columas DTYPE for each record type in Section IV. The data type and the data value may be connected by a relational operator from the following list.

$\begin{array}{ll}\text { EQ or }= & \text { equal to } \\ \text { LE } & \text { lese thas or equal to }(\leq) \\ \text { LT or }< & \text { lese than } \\ \text { GT or }> & \text { greater than } \\ \text { GE } & \text { greater then or equal to }(Z) \\ \text { AP } & \text { approximately equal to }(z) \\ \text { SY } & \text { obtained from systematice } \\ \text { CA } & \text { calculated velue }\end{array}$

The alphabetic representations muat contain a blank on alther side, 1.e.,"GT_", "_AP_". 


\section{DETAILED FELD DESCRIPTIONS}

\section{A. NUCID}

The standard nucleus identification consists of two to five characters giving the A-value and the chemical symbol of a melens, e.E., 9B, 20F, SoRU, IT7HF. The meleus identification must be contained within the field defined for it (cols. 1-5 on most cards). It is recommended that the melens idemification always begin in col. 1; i.e., it is left-adjusted. The anclens idantification mant be included ca erery IDENTIFICATION record. It is atrongly recommended that it also be included on every card of a data set except the END record. Mis is done antomatically whes the data set is filed onto the duta cell.) The data set will be houlled correctly if all cards except the IDENTIPICATION record contain biams in the NUCID field, but wech decks are rery difficult to edit.

\section{B. DSID}

The content of a data set is described in a standand way in the DBD field of the WENTIFICATION record. The standards may be described ander three general beadings: 1) decay data sets, 2) reaction data sets, 3) "adopted" data sets.

1. Por a duta set describing the rewults of a measurement of radionctive decay, the DSD field contains three parts separated by one or more blanks the decaying maleue, the type of decay, and the word "DECAY", e.E.,

$\begin{array}{llll}22 N A & \text { B+ } & \text { DECAY } & \\ 64 Y & \text { B- } & \text { DECAY } & \\ 1341 & \text { IT } & \text { DECAY } & (3.7 \mathrm{M}) \\ 134 & \text { B- } & \text { DECAY } & (3.7 \mathrm{M}) \\ 1341 & \text { B- } & \text { DECAY } & (52.6 \mathrm{M}) \\ 133 B A & \text { EC } & \text { DE2AY } & \\ 214 A T & A & \text { DECAY } & \\ 252 C F & \text { SF } & \text { DECAY } & \end{array}$

A half-life (in parentheses) may be added to apecify the decas completely. The decaying nucleus is identified by its standard NUCID (Section VI.A).

Five decay types are recognized in the DSID tield:

\begin{tabular}{|c|c|}
\hline & B-decay \\
\hline B+ & elestron capture and/or $\beta^{\dagger}$-decay (EC is preferred) \\
\hline A & a-decay \\
\hline $\begin{array}{l}\text { IT } \\
\text { SF }\end{array}$ & $\begin{array}{l}\text { Inomeric state decay (1-radiation only) } \\
\text { epontaneous fission }\end{array}$ \\
\hline
\end{tabular}


2. For a dula set describing rewitte of a melear reaction study, the DSD field contains the target and the incowies and outoine perticles suct as:

\author{
20NE $(\mathbf{P}, \mathbf{D})$ \\ 4eCA $\left(A, A^{\prime}\right)$ for $\left(a, e^{\prime}\right)$ \\ ICSAG(SOAR, HOAR') \\ $\operatorname{sozR}(A, 4 N G)$ \\ use $4 \operatorname{ssc}(N, G), E=T H ;$ mever $45 s c(T H ~ N, G)$
}

The taryet meleas and the reacting particle mas be given in the sundard form fee NUCID, Section VI.A). A reaction eners mis be girea dhea desired or seeded. The reccins partictes was alterantively be tulea from the list of abreviations:

\begin{tabular}{|c|c|}
\hline $\mathbf{P}$ & proton (1I) \\
\hline $\mathbf{N}$ & nestron \\
\hline $\boldsymbol{A}$ & a-particle (MHE) \\
\hline D & denterven (24) \\
\hline $\mathbf{T}$ & triton (3ad) \\
\hline $\mathbf{G}$ & $y-r a y$ \\
\hline $\mathbf{u}$ & $\mu$-meson \\
\hline PO & $x$-meson \\
\hline NU & neutrino \\
\hline $\mathbf{E}$ & electrot \\
\hline
\end{tabular}

3. An "ADOPTED" date set costann the beat representation of the present experimeatal knowledse bout the levels of a meleus. The data set will be named

\title{
ADOPTED LEVELS.
}

If all level information for a maclens is contabed in a data set for a single experiment, it is not peceasary to make an additional ADOPTED date set as well. However. If more then one experimental data set comains level information sbout the wacleus, thea a separate ADOPTED data set MUST be made, even if the ADOPTED data set contains only the Q-VALUE record and a simple ground-state LEVEL record.

An ADOPTED data set always contains (in its IDENT! FICATION record) a referesce to the Nuclear Data sheets or simitar evaluation where the supporting data have been compared.

An ADOPTED data set contains a Q-VALUE record (e.8., as produced by the Alomic Mases Adjustment Program), which includes at least $Q_{p}, s_{n}, s_{p}$, if available.

An ADOPTED date set containe a LEVEL record for every level that has been reliatly observed. GAMMA records may also be iacluded in an ADOPTED data cet. 


\section{DEREF}

References 10 spportios poblicutions or andyses are placed in this field by

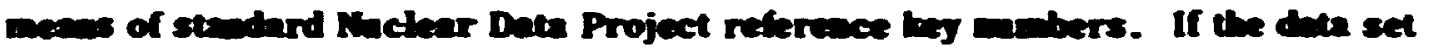

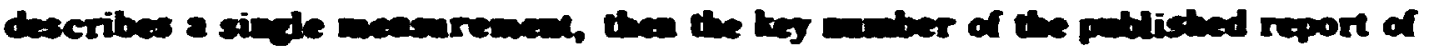

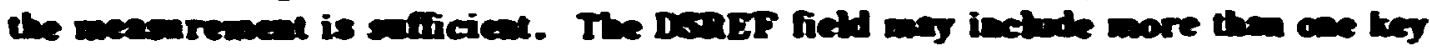

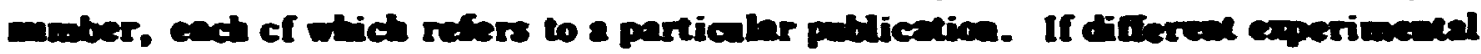

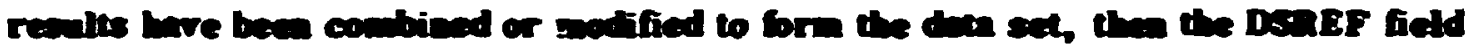

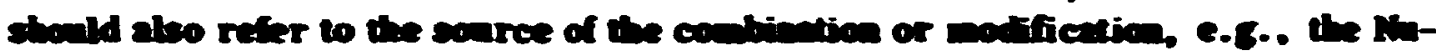

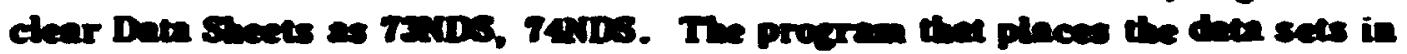

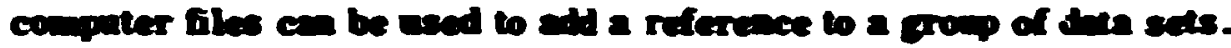

The DsaEF fictd will be ased wootly by the Neclear Deta Project to beep records of oflich data hove superseded or been modified by others. The DeSaEF Gield will be so axsiend thet distinet data sets will also bove distinct DSaEF

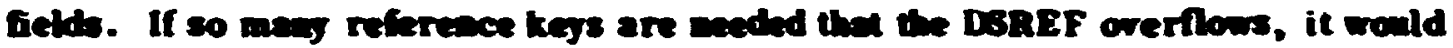
be better to pot reference heys in a comben record and use only the KDS refereace in the DSREF field.

\section{ETYPE}

A sinde-letter code thet gives a mane to the RECORD ispe.

\begin{tabular}{|c|c|}
\hline BTYPE & Description \\
\hline Blank & Mas be IDERTIFTCATIOA recond or END record \\
\hline $\mathbf{N}$ & NORMAUZATON record \\
\hline $\mathbf{P}$ & PAREAT record \\
\hline $\mathbf{Q}$ & Q-VALUE record \\
\hline $\mathbf{L}$ & LEVEL record \\
\hline $\mathbf{G}$ & GALIM recond \\
\hline $\mathbf{B}$ & B- record \\
\hline $\mathbf{E}$ & EC (or EC + B+) record \\
\hline $\mathbf{A}$ & ALPHA recond \\
\hline
\end{tabular}




\section{UACERTARTtLS}

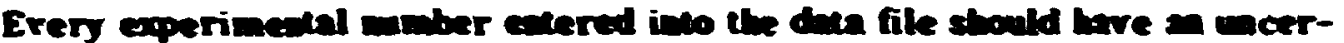
tainty asociated with it if a all ponsible. Uncertainties may be maneric or won-

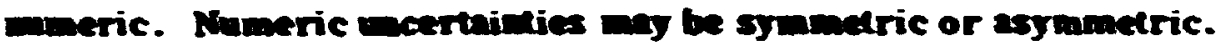

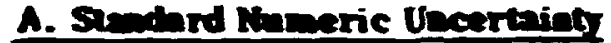

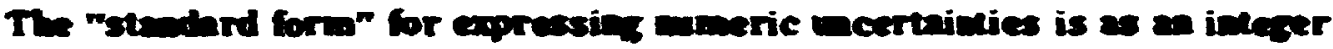
meertains in the least signifient ditits) of the coperimental maber, i.e.. 44.7 $\pm 0.7 \rightarrow 40.7$ 7; $0.3721 \div 0.0014-0.3721$ 14. The RTY PE for a stadand meertaines is weally lormed by adding the prefix D to the RTYPE of the detum, C.E.. E, DE; RI, Dal; MV, DuV.

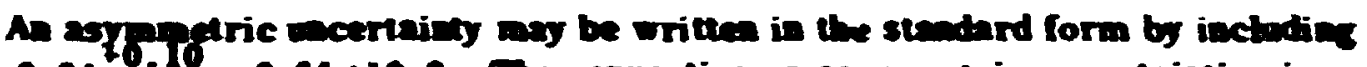
sigas; $0.84-0.03-0.44+10-3$. The convention on eysmmetric uncertainties is thet they contive alzebraically with the datem, wet that $-3_{-4}^{+1}$ describes a rage from $-710-2$.

\section{B. Noe-pheric Uecortaindice}

The nom-maneric uncertaimies inchede the symbols for approximate, calculated, systematics, ad aleo the relational opermors act as greater-thon, leas-

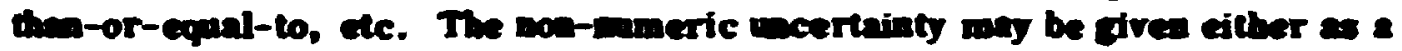
symbol or as a two-letter code in the uscertainty field:

\section{Srmbol Letier code Nemin}

\begin{tabular}{|c|c|c|}
\hline $\begin{array}{l}x \\
>\end{array}$ & $\begin{array}{l}\mathbf{A P} \\
\mathbf{G T}\end{array}$ & $\begin{array}{l}\text { eproximately equal to } \\
\text { creater then }\end{array}$ \\
\hline zor $>*$ & GE & preater then or cound to \\
\hline$<$ & $\mathbf{L T}$ & Ifes then \\
\hline$\leq$ or $<x$ & $\begin{array}{l}\text { LE } \\
\text { SY }\end{array}$ & $\begin{array}{l}\text { less then or qual to } \\
\text { grolematics }\end{array}$ \\
\hline & CA & calculated \\
\hline & TH & theoretical \\
\hline
\end{tabular}


VIII. EXPECTED AND ALLOWED UNITS

A. Half-lives must include units, Use

$$
\begin{aligned}
& F S=10^{-15} \mathrm{~s} \\
& \mathbf{P S}=10^{-12} \mathrm{~s} \\
& \mathbf{N S}=10^{-9} \mathrm{~s} \\
& \mathbf{U S} \equiv \mu \mathrm{s}=10^{-6} \mathrm{~s} \\
& \mathbf{M S}=10^{-3} \mathrm{~s} \\
& \mathbf{S}=\text { second } \\
& \mathbf{M}=\text { micute } \\
& \mathbf{H}=\text { hour } \\
& \mathbf{D}=\text { day } \\
& \mathbf{Y}=\text { year } \\
& \mathbf{K Y}=10^{3} \text { year } \\
& \mathbf{M Y}=10^{6} \mathrm{y} \\
& \mathbf{G Y}=10^{9} \mathrm{y}
\end{aligned}
$$

Computer-standard exponential format may be used. Examples:

$$
\begin{aligned}
& \text { 3.7 PS }=3.7 E-12 \mathrm{~S} \\
& 4.21 \mathrm{GY}=4.21 E 9 \mathrm{Y}
\end{aligned}
$$

B. Signs of certain experimental quantities (nuclear moments, y-ray mixing ratios) are as important as the numbers, thomselves. If the sign is known, it should be given explicitly. If the sign is not known, then the absence of any sign is just as descriptive as the +- (or \pm ). If a value is known to be $>0$, it must have a sign.

\section{FREE-FORM FIELDS}

A free-form field on any card is a region on the card where the input data values are self-descriptive; i.e., the field contains character strings sich as E.KC $=0.1045$ or BE2 $<0.5$. The second, third, etc., cards for any riscord (when permitted) contain one free-form field between cols. 10-80 (see Section V.B).

A free-form field contains character strings of the form:

$$
\text { (data type)(cperator)(data value). }
$$

The "data types" are restricted to the permitted names given under DTYPE in Section IV for the appropriate record type. The "data value" is a numerical or character-string value. A numerical data value may have an associated uncertainty (Section VII). The "operator" may be a mathematical symbol or its alphabetic representation. 


$\begin{array}{ll}\text { EQ or }= & \text { equal to } \\ \text { LE } & \text { less than or equal to } \\ \text { LT or }< & \text { less than } \\ \text { GE } & \text { greater than or equal to } \\ \text { GT or }> & \text { greater than } \\ \text { AP } & \text { approximately equal to }\end{array}$

(The alphabetic representation must inchude at least one blank on , ach side, e.g., CEK_LT_27.4, but not CEK_LT27.4.) The character strings (data ispe + operator + data value) may be separated from each other by one or more blanks. 
25

APPENDIX

Sample Data Sets 


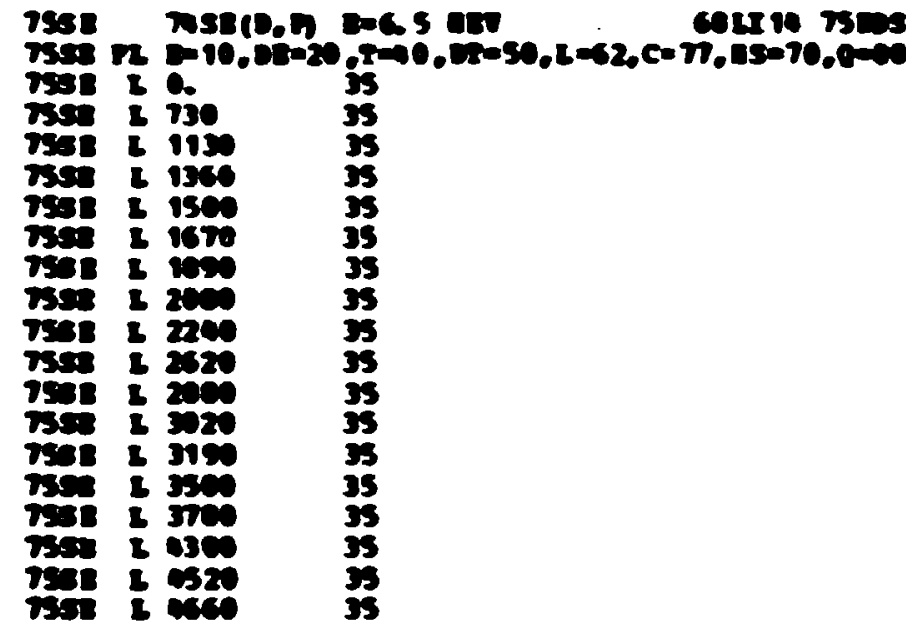

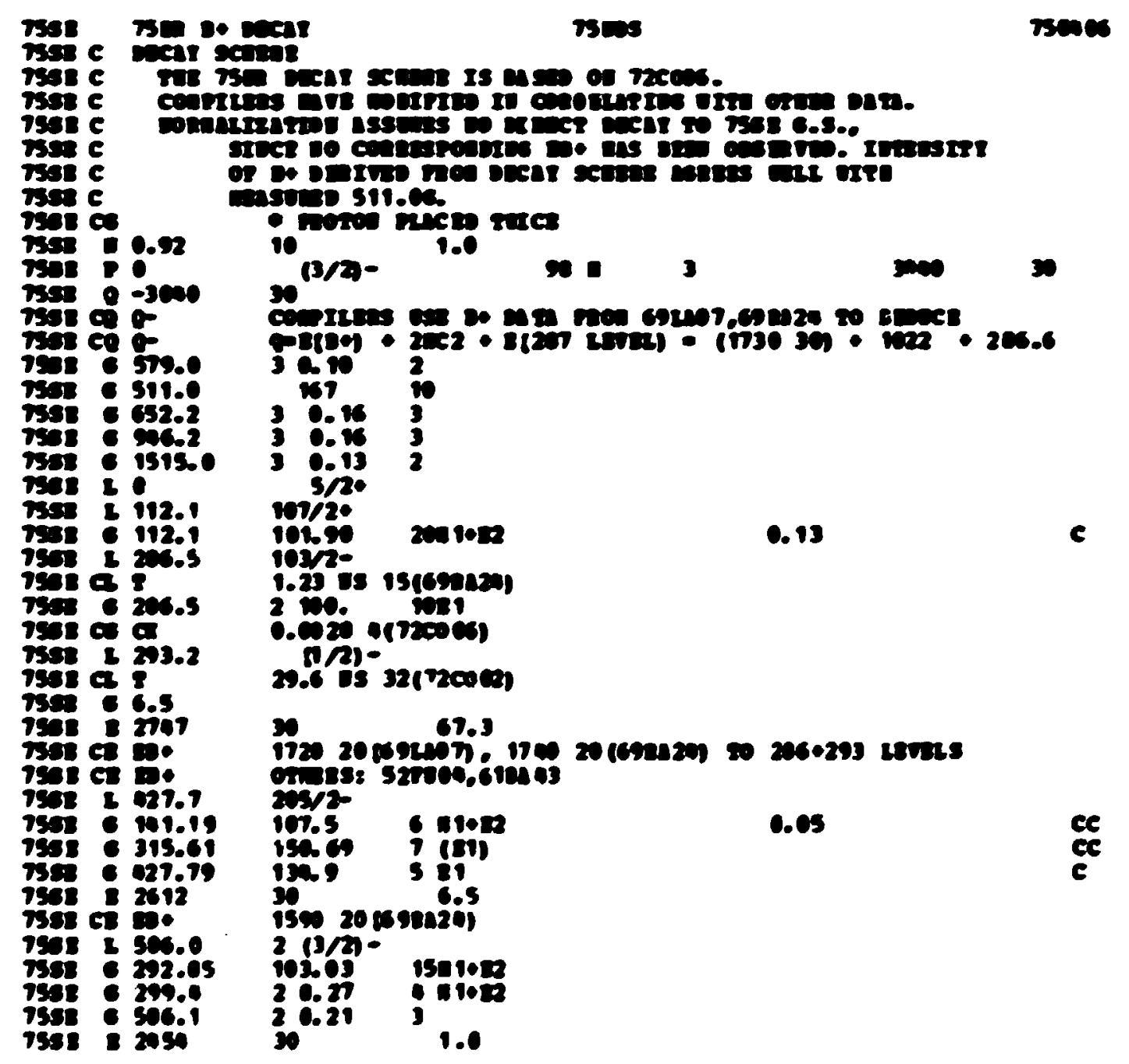




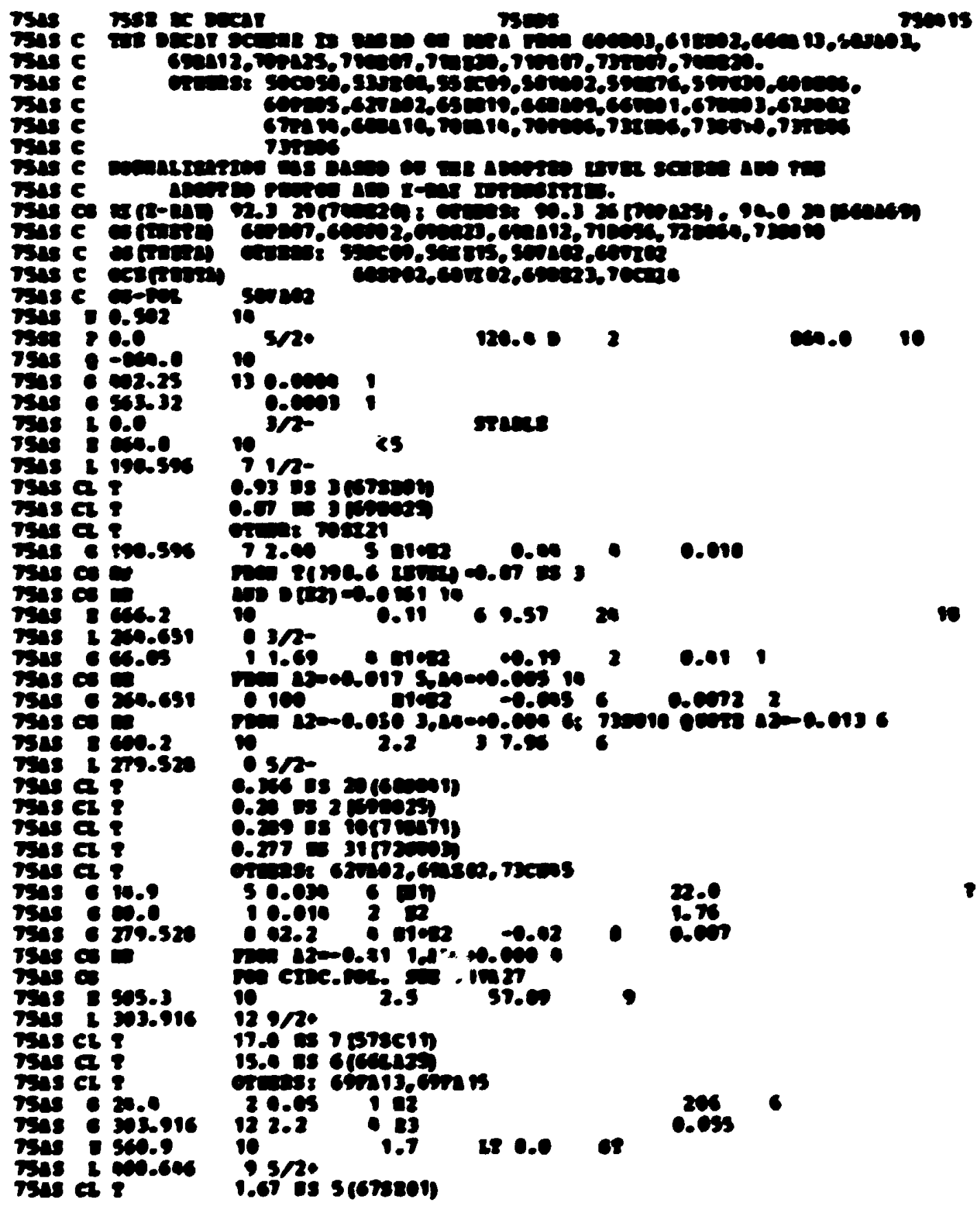




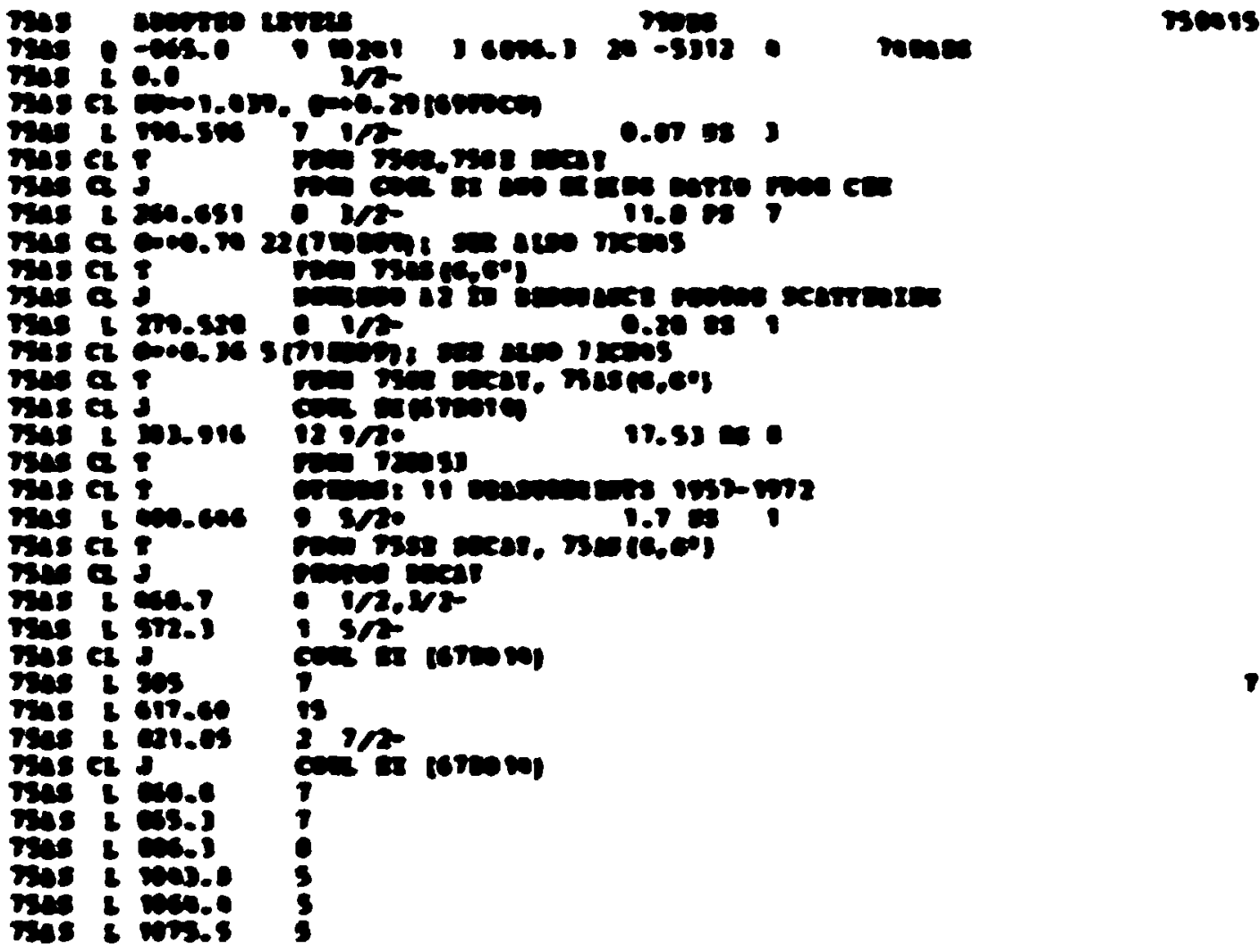

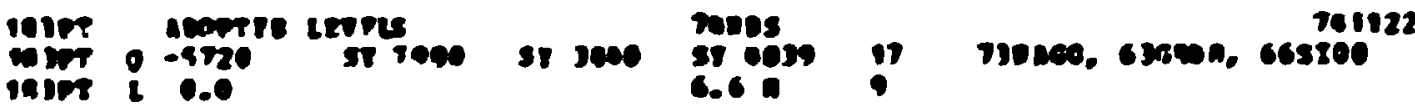

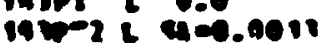

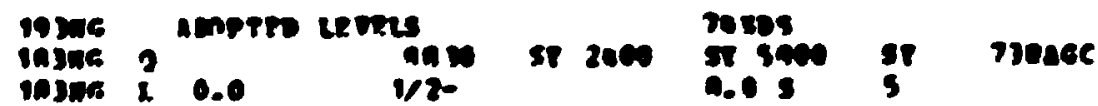




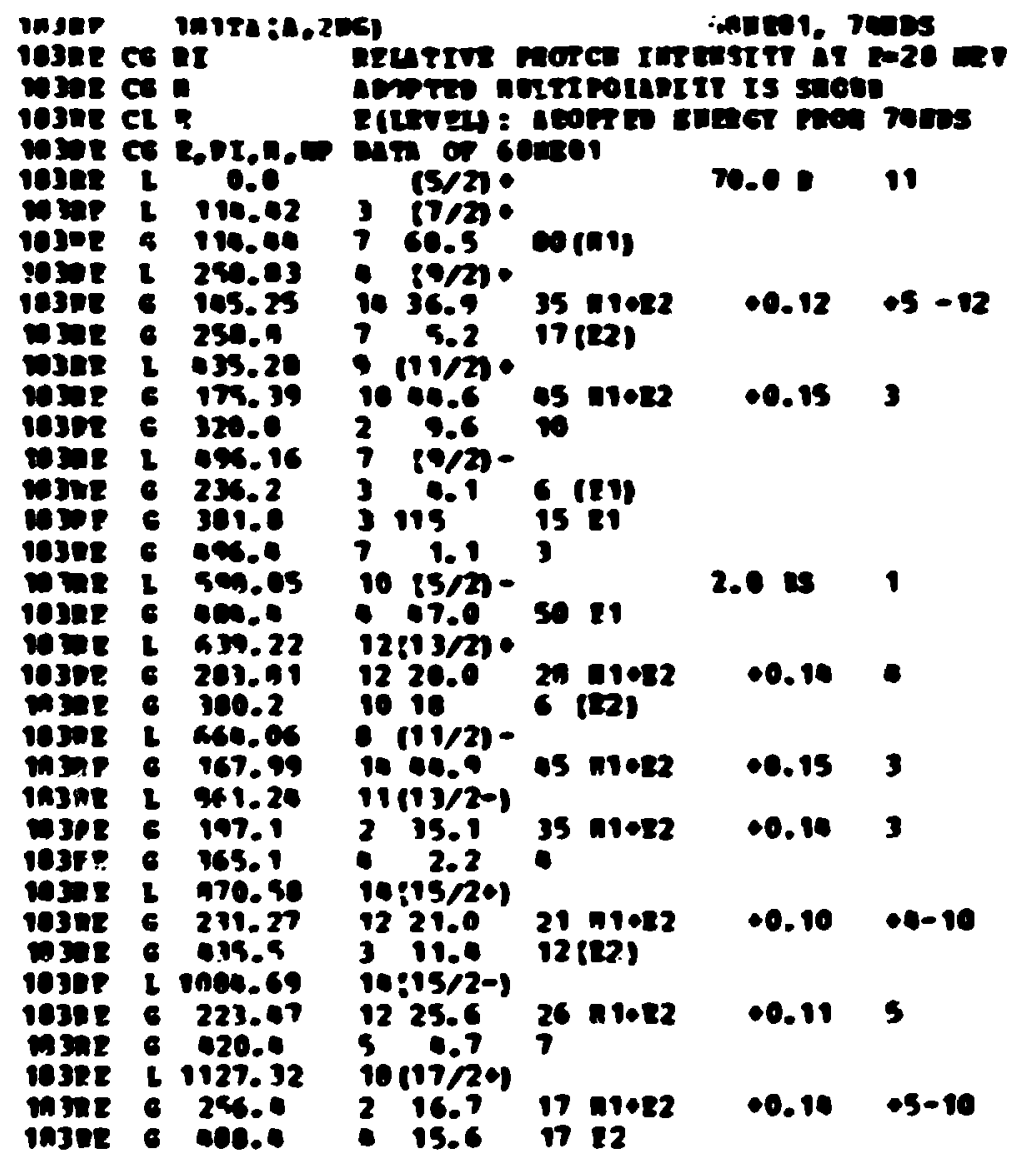



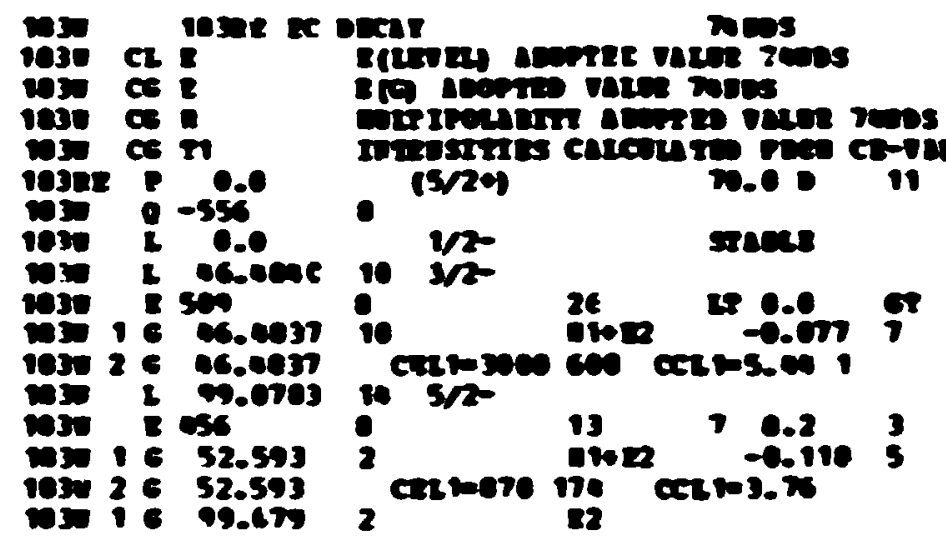

E(civas curret were zons

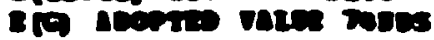

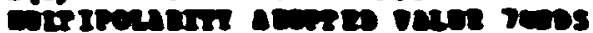

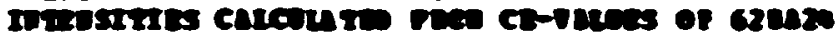

(sizes

1/20 $\sec$

10

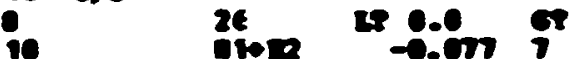

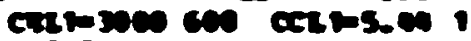

ass 1172

is

$10 \sin$

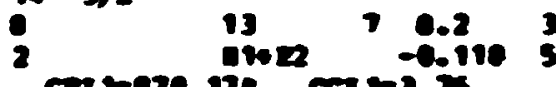

2

17. $\cos 3.5$

6215205

41 10 c

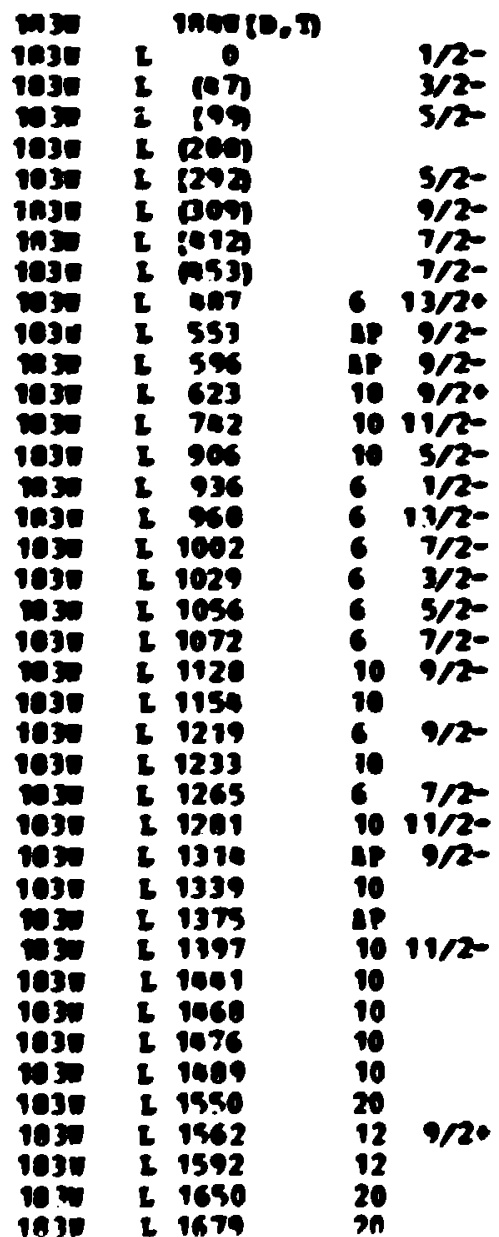

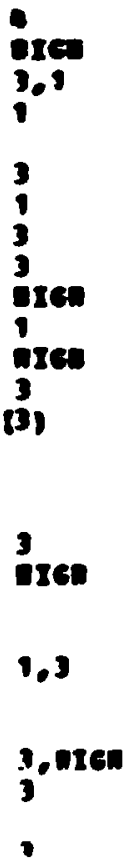

